\title{
OBITUARY
}

\section{DR JONATHAN WRIGHT}

Although Dr Wright had retired from active practice many years ago, his recent death which we regret to report, will recall to many, a brilliant personality, who was one of the pioneers of laryngology in America.

He was connected at various times with the Roosevelt Hospital, the De Milt Dispensary and the Manhattan Eye and Ear Hospitals and had an extensive practice in Brooklyn and New York.

He was the author of two books, one a History of Laryngology and Rhinology in I 902, the other a text book of Diseases of the Nose and Throat, with Dr Harmon Smith in I9I4.

Besides this he made many investigations in a variety of directionsAtrophic Rhinitis, Lymphoid cysts, and Tuberculosis of the upper air passages being but a few. He was particularly interested in the pathological conditions underlying disease and in more recent years was responsible for the pathological chapter in Sluder's book on Headaches of Nasal Origin.

In addition, he was a very considerable Classical scholar and employed his leisure in belles-lettres and philosophy at the country home to which he had retired.

Walter Howarth.

\section{MR ARTHUR H. CHEATLE}

THE death of Arthur Cheatle has removed from the otological firmament one of its very brightest stars.

He was born sixty-two years ago and with the exception of a slowly developing deafness, which did not appear so marked to those around him as it did to himself, he presented the picture of manhood vigorous both in body and mind up till the last year or so. It was only then that a vascular lesion struck him down and that he disappeared from our midst to pass away from this life on the I I th of May. In his early days the present writer was asked by a mutual friend to lend a helping hand to our late colleague, apparently unconscious of the irresistible energy and ability with which he was so richly endowed and of his independence of any outside help, however well intentioned.

His education was obtained at Merchant Taylors' School and King's College Hospital. He took the Fellowship of the Royal College of Surgeons in 1892 and was duly appointed Assistant Aural 